DOI: https://doi.org/10.18371/fp.4(36).2019.190324

УДК 336.71

\title{
БАНКІВСЬКЕ КРЕДИТУВАННЯ В СИСТЕМІ ЕКОНОМІЧНОЇ БЕЗПЕКИ УКРАЇНИ
}

\section{ЧЕПЕЛЮК Ганна Миколаївна}

доцент, кандидат економічних наук

доцент кафедри фінансів та банківської справи, ДВНЗ «Університет банківської справи», Черкаський навчально-науковий інститут

ORCID ID: https://orcid.org/0000-0003-0839-8407

e-mail:Chepelyk.b@ukr.net

\section{Гриценко Катерина Юріївна}

магістрант, ДВНЗ «Університет банківської справи», Черкаський навчальнонауковий інститут

ORCID ID: https://orcid.org/0000-0002-1322-0059

e-mail:kat.grytsenko@gmail.com

Анотація. В статті досліджено роль банківського кредитування, взаємовідносини між банками та реальним сектором економіки, проблеми збалансованості та узгодженості перспективних макроекономічних иілей в економічному розвитку України. Банківське кредитування розглядається як ключовий елемент економічного зростання, та має безпосередній вплив на забезпечення суверенітету держави, реалізацію ї̈ національних інтересів в умовах глобалізащійних проиесів.

Ключові слова: кредитування, фінансова безпека, економічна безпека, ризики, індикатори банківської безпеки

Постановка проблеми. Економіка країни суттєво залежить від ефективності функціонування банківської системи. Банки активно впливають на сферу виробництва та соціальноекономічні процеси у суспільстві.
Аннотация. В статье исследована роль банковского кредитования, взаимоотномения между банками и реальным сектором экономики, проблемы сбалансированности и согласованности перспективных макроэкономических иелей в экономическом развитии Украины. Банковское кредитование рассматривается как ключевой элемент экономического роста, и имеет непосредственное влияние на обеспечение суверенитета государства, реализачию ее национальных интересов в условиях глобализационных прочесcoв.

Ключевые слова: кредитование, финансовая безопасность, экономическая безопасность, риски, индикаторы банковской безопасности

Дисбаланс в економіці призводить до порушення економічного циклу відтворення та формує диспропорції між реальним та фінансовим сектором економіки. Внаслідок цього порушується закономірність процесу 
економічного розвитку. Основним інструментом впливу банків на розвиток економіки, як правило, $є$ кредитування. Це обумовлено закономірністю бізнесу спрямовувати капітал у сфери, які мають найвищу норму прибутку. Кредитні операції є одним як із ефективних способів вкладення залучених ресурсів банку, так і найбільш ризиковим напрямком його діяльності. На макроекономічному рівні кредитування виступає одним із чинників формування рівня фінансової безпеки як частини економічної безпеки України.

Аналіз останніх досліджень та публікацій. Проблеми економічної, в тому числі й фінансової безпеки держави розглянули у своїх працях науковці: О. І. Барановський, 3. С. Варналій, В. М. Геєць, О.В. Дзюблюк, Л.В. Жердецька, М.І. Звєряков, О.Л. Малахова, Т.В. Черничко та інші.

Проблема взаємодії реального та банківського секторів економіки є однією із найбільш актуальних проблем, що досліджується у вітчизняній та зарубіжній економічній літературі, присвяченій особливостям становленню ринкових відносин. Українські вчені О.В. Дзюблюк та О.Л. Малахова у своій монографії «Банки і підприємства: кредитні аспекти взаємодії в умовах ринкової трансформації економіки» вірно зазначають, що спад інвестиційної активності до критичного рівня та хронічне недофінансування виробничих фондів реального сектору економіки призвели до нагромадження на діючих підприємствах значного об'єму знеціненого кризами морально i фізично зношеного обладнання, погіршення його промислових характеристик, інтенсивного старіння вироб- ничих потужностей i, як наслідок, до різкого зниження конкурентноздатності вітчизняних підприємств. Спад виробництва, руйнування відтворювального контуру підприємств і майже повна відсутність можливостей до їх самофінансування формують підвищені очікування до наявності зовнішніх (по відношенню до підприємств) інвестиційних ресурсів та обумовлюють, зокрема, потребу у значних обсягах банківських кредитів, які у зв'язку із інертністю реального сектору повинні бути достатньо довгостроковими [4, с. 10].

Як зазначають М.І. Звєряков та Л.В. Жердецька, сучасні емпіричні дослідження взаємозв'язку економічного зростання та розвитку фінансової системи поділяють за такими основними напрямами:

- перевага пропозиції (supplyleading) (коли фінансовий розвиток визначає економічне зростання);

- слідування за попитом (demand-following) (коли економічне зростання визначає рівень розвитку фінансового ринку);

- так званий «змішаний зв'язок» (коли чіткого причинно-наслідкового зв'язку між цими економічними змінними встановити неможливо) [5].

O. I. Барановський у своїй фундаментальній праці - монографії «Філософія безпеки» грунтовно аналізує виклики та загрози для банківського сектору. На думку вченого, більшість нових тенденцій у банківському секторі пов'язані з глобалізацією. Сам процес глобалізації економіки є викликом для банківського сектору економіки. [1, с. 156-165]. 
Як слушно зазначає 3. С. Варналій, фінансова система держави становить сукупність як усіх фінансових інститутів, так і тих органів та установ, які займаються фінансовою діяльністю в межах своєї компетенції. Розвал однієї ланки фінансової системи призведе до розвалу системи в цілому. Саме тому пріоритетним напрямком економічної безпеки є фінансова безпека, але поряд 3 нею в системі економічної безпеки виділяють також інформаційну, техніко-технологічну, правову, кадрову та інші види безпеки [2].

Враховуючи значні наукові доробки вітчизняних та зарубіжних науковців, вважаємо за доцільне на їх базі розглянути емпіричні дані щодо кредитування в Україні з точки зору його впливу на рівень фінансової безпеки як складової економічної.

Мета статті полягає у розробці пропозицій щодо оцінки банківського кредитування на основі аналізу емпіричних даних, його ролі та впливу на економічну безпеку України із врахуванням основних викликів та загроз.

Виклад основних результатів. Питання фінансової безпеки банків у трансформаціях потреб економіки та суспільства є одним із першочергових, актуальним i важливим. Нерівномірність руху основних та оборотних засобів у процесі суспільного виробництва відображається у тимчасовому дефіциті грошових коштів в одних суб'єктів економічної діяльності та тимчасового надлишку в інших. Це й виступає передумовою виникнення кредитних відносин. Вважаємо доречним короткий огляд передумов для нинішнього стану банківсько кредитування економіки України.
Т.В. Черничко виділяє чотири періоди у розвитку кредитних відносин в Україні за час незалежності [10]:

1. Період 1: 1991-1992 pp. - період становлення нового типу кредитних відносин на базі соціалістичних форм і видів кредитування. Зростання обсягів наданих кредитів відбувається шляхом розширення переліку суб'єктів кредитних відносин, в умовах відсутності досвіду ринкових відносин 3 позичальниками та сформованого правового поля. Саме в цей період «...відновлюється істинна сутність кредиту як самостійної економічної та базової категорії в кредитному механізмі, припиняється безповоротне фінансування видатків бюджету, надання кредитів збитковим господарствам, а також на цілі, які не відповідають внутрішній природі кредиту і принципам комерційної діяльності» [3, с. 38].

2. Період 2: 1993-1999 рр. - період значного зменшення обсягів наданих кредитів та перехід до товарної форми кредитування. У лютому 1993 р. НБУ затвердив Порядок проведення банками операцій 3 векселями, яким було встановлено особливості застосування комерційного кредиту. У цей період практично призупиняється довгострокове інвестиційне кредитування. Фінансовий стан як суб'єктів господарювання, так і комерційних банків погіршується. На фоні зростання попиту на кредити це призводить до зростання відсоткових ставок. Найбільш критичного стану ситуація в банківській системі досягла в 1996 році під час фінансової кризи.

3. Період 3: 2000 - 2008 рр. - період динамічного зростання обсягів кредитування в економіці України. Відбу- 
вається процес відновлення інвестиційного кредитування. Пік обсягів кредитів, наданих комерційними банками, - 2006 - 2008 рр. У цей період зростання кредитного портфеля відбувається на 60-80\% щорічно (у 2006 році - на $72 \%$ від попереднього року, у 2007 році - на $80 \%$, 2008 році - на $63 \%$ ). При цьому в структурі наданих кредитів переважає частка кредитування юридичних осіб - 60-94\%. Значне зростання обсягів кредитних ресурсів у 2008 р. пов'язане 3 переоцінкою кредитів в іноземній валюті внаслідок девальвації гривні. Саме на цьому етапі формується система парабанківських кредитних установ.

4. Період 4: з 2009 року - характеризується зменшенням кредитних вкладень в економіку країни. Основні причини: значний відплив депозитних ресурсів унаслідок фінансової дестабілізації в 2008-2009 pр. та зростання недовіри до банківської системи; призупинення взаємного кредитування банками на міжбанківському ринку.

5. Додамо період 5 думкою колективу науковців та практиків, викладену в аналітичному дослідженні «Новий економічний курс України: стратегія інноваційного розвитку» $[9$, с. 401]. Номінальне зростання кредитного портфеля внаслідок трикратної девальвації гривні порівняно 32013 роком. Окрім того, структурні диспропорції банківських балансів різко погіршились і спровокували системну банківську кризу. Несвоєчасна та невиважена реакція регулятора не сприяла оперативному вирішенню цієї проблеми, а навпаки призвела до поглиблення кризи і зростання соціально- політичних ризиків. Після ліквідації третини банківської системи, до існуючих раніше системних проблем додалася нова - погіршення структури банківського ринку: зростання концентрації іноземного капіталу і зниження рівня конкуренції. Згідно з рейтингом глобальної конкурентоспроможності Всесвітнього економічного форуму у 2015 та 2016 роках Україна продемонструвала найгірший результат за показником «міцність банків» серед 140 та 138 країн відповідно.

При дослідженні економічного зростання, яке визначає економічну безпеку країни, науковці вивчають низку економічних, соціальних, політичних та інституціональних чинників, які на нього впливають. Результати аналізу Р. Барро за даними ста країн за період у тридцять років свідчать, що зростанню ВВП сприяють: його більш високий початковий рівень, відповідні рівні освіти, тривалості життя, більш низькі рівні народжуваності, державного споживання та інфляції, дотримання законів і покращення умов торгівлі [12]. У дослідженнях інших вчених проаналізовано економічні чинники: зростання експорту, нагромадженням капіталу, рівень державного споживання, дефіцит чи профіцит державного бюджету та інфляція [13].

Необхідно відзначити, що сьогодні НБУ також визнає важливість розвитку взаємодії банківського 3 реальним сектором економіки. Його опосередкований вплив досить суттєвий на розвиток галузей економіки. 3 метою організації ефективного зворотного зв'язку з реальним сектором економіки, НБУ постійно модернізує систему збору та аналізу інформації, формує 
інформаційний простір для аналітичної діяльності. Прогнозування розвитку галузей реального сектору економіки в середньостроковій перспективі вважаємо дієвим заходом щодо посилення фінансової та економічної безпеки України. Передбачення можливих проблем взаємодії бізнесу та населення з банками уможливлює для органів державного управління своєчасно вносити корективи в економічну політику.

Економічну та фінансову безпеку в контексті банківського кредитування визначають показники, наведені у Методичних рекомендаціях щодо розрахунку рівня економічної безпеки України, затверджені наказом Міністерства економічного розвитку і торгівлі України від 29.10.2013 р. № 1277 [8].

Показники, що стосуються кредитування, виступають складовими значної кількості індикаторів фінансової безпеки та включені до індикатора інвестиційно-інноваційної безпеки. Виходячи 3 наведеного, вважаємо кредитування інструментом підвищення ефективності фінансового забезпечення діяльності реального сектору економіки та перспективним інструментом підвищення рівня економічної безпеки.

Розглянемо емпіричні дані, що стосуються кредитування 3 точки зору його впливу на фінансову та економічну безпеку України. Станом на 01 січня 2019 року ліцензію НБУ мали 78 банківські установи, в тому числі 41 банк $з$ іноземним капіталом, із яких 24 банки мають $100 \%$-й іноземний капітал. Порівняно з 2016 роком, загальна кількість банків зменшилася на 21 (2016 - 99 банків), кількість банків 3 іноземним капіталом залишилася незмінною, кількість банків зі 100\%-м іноземним капіталом збільшилася на 6 (2016 - 18 банків). За даними проміжної звітності 2019 року, на 01 грудня в Україні ліцензію НБУ мають 75 банків, в тому числі 35 банків з іноземним капіталом, із яких 23 банки мають 100\%-й іноземний капітал. 3 точки зору контролю, - 5 банків і надалі контролюються центральними органами держуправління, а 70 - приватні [7].

Результати аналізу основних показників банківського кредитування у контексті їх впливу на реальний сектор економіки за 2016-2018 роки свідчать про те, що у 2016-му році про невисоку активністю кредитних установ. Протягом 2017 року обсяг кредитів у житлову нерухомість скоротився на 10281,53 млн. грн. та станом на 01.01.2018 р. відповідав 48267,86 млн. грн. проти 58549,39 млн. грн. на початок 2017 року. 2018 року обсяг даного кредитного портфеля зменшився на 3809,83 млн. грн. та станом на 01.01.2019 р. склав 44458,03 млн. грн. Кредити у комерційну нерухомість протягом 2017 року зменшилися на 506,4 млн. грн., втім, 2018 -го відбулося зростання на 22930,04 млн. грн. Дану тенденцію можна назвати позитивною, оскільки відбувається хоч і незначне, але вкладення коштів у нерухомість бізнесу. Загалом, невисокі темпи розвитку іпотечного кредитування обумовлені доволі низькими темпами відновлення будівельної галузі, обмеженістю та високою вартістю довгострокового ресурсу, а також невисоким платоспроможним 
попитом населення-підприємців на довгострокові кредити.

Кредити в іноземній валюті протягом 2017 року зменшилися (26812,69 млн. грн.) проти 2016-го, але вже у 2018-му зросли порівняно 32017 роком на 28648,81 млн. грн. Зміни показника за недіючими кредитами характеризуються зростанням. Це $\epsilon$ негативним явищем. Водночас, можна назвати позитивним фактом те, що темпи цього зростання суттєво зменшилися - 35768,1 млн. грн. у 2018-му проти 194005,38 млн. грн. 2017-го.

Ліквідні активи (широкий показник) i3 кінцевим строком погашення до одного року демонструють стабільне зростання, що загалом підвищує загальну оцінку фінансової стійкості банківської системи.

Щодо якості кредитного портфеля банків 3 точки зору фінансової та економічної безпеки, то ризик погіршення стосується кожного конкретного банку окремо. Втім, у випадку системного порушення позичальниками своїх зобов’язань перед банками, може стати причиною збитковості всієї банківської системи.

Варто також виділити непрацюючі кредити в розрізі груп банків. За даними Звіту НБУ про фінансову стабільність за грудень 2019 р. за період із 30.06.2017 по 31.10.2019 p.p., - найменша питома вага непрацюючих кредитів спостерігається в іноземних банків, окрім російських. Причому, якщо питома вага непрацюючих кредитів в інших іноземних банків знизилася удвічі (від $38 \%$ до $19 \%$ ), то в російських, навпаки, - зросла за два роки від $67 \%$ до $87 \%$. На даний момент на українському ринку продов- жує працювати два банки з державним російським капіталом це Сбербанк і Промінвестбанк.

3 українських банків найбільш проблемним залишається АТ КБ «ПриватБанк», що був націоналізований. Якщо порівняти динаміку зміни питомої ваги проблемних кредитів, то вона порівняна 3 іншими державними банками, а саме: незначне зменшення (10 \% за два роки). Решта державних банків знизили цю частку на 11 \% за аналогічний період.

Аналіз кредитів за інституціональною ознакою показує, що за останні три повні звітні роки (2016-2018 рр.) портфель кредитів, наданих нефінансовим корпораціям, у банківській системі України характеризувався певною нестабільністю і нерівномірним розподілом у розрізі цільового спрямування, термінів і валют.

У розрізі цільового спрямування, найбільше видано інших кредитів (2016 - 98,64 \%, 2017 - 98,7 \%, 2018 96,1 \%). У розрізі валют перевага надається національній валюті (2016 $50,77 \%, 2017$ - 54,83 \%, 2018 - 53,97 $\%)$.

3 точки зору строковості, то найбільшим попитом протягом 2017 2018 років користуються короткострокові кредити. 2016 року більшість кредитів складали середньострокові. Довгострокові кредити складають найменшу питому вагу в загальній структурі кредитів (2016 - 19,74\%, 2017 - 22,41 \%, 2018 - 19,53 \%). Розподіл кредитів за строками надання свідчить про недоступність довгострокових кредитних ресурсів для більшості корпоративних позичальників. 
У розрізі валют спостерігаємо, що головну позицію серед валют, у яких надаються корпоративні кредити, займає гривня (54\%), натомість серед валютних кредитів переважають позики у доларах США (37 \%) та євро (9\%).

Вважаємо, що 3 точки зору посилення економічної безпеки, позитивною була тенденція до зростання частки довгострокових кредитів 2017 року, оскільки саме вони надаються переважно на цілі, пов'язані з будівництвом, переоснащенням тощо. У 2018 році довгострокові кредити зменшилися за обсягами як в абсолютному вимірі, так і за структурою. Зазвичай, отримання доходу від інвестиційного проекту перевищує термін одного року, тому інвестиційні кредити $є$ ще й довгостроковими. Більшість українських банків мають помірні значення питомої ваги валютного кредитного портфеля, валютних зобов'язань та валютних вкладів населення. Натомість найбільшу питому вагу кредитів та зобов'язань в іноземній валюті, мають, в основному, банки 3 іноземним капіталом.

Як слушно зазначають Н.Я. Юрків, Д.М. Гладких у своїй аналітичній доповідi «Розвиток банківського кредитування господарюючих суб'єктів як умова забезпечення сталого економічного зростання в Україні» [11], поточна структура кредитного портфеля нефінансовим корпораціям у розрізі валют, очевидно, не $\epsilon$ оптимальною 3 точки зору фінансової безпеки у зв'язку з надмірною питомою вагою валютних кредитів, що формує додаткові ризики, пов'язані з курсовою нестабільністю, та не відповідає стра- тегічному завданню поступової дедоларизації грошової маси.

Таким чином, можна узагальнити, що протягом 2018 року кредитна активність банківських установ зросла. Серед основних факторів, що гальмують відновлення необхідних обсягів кредитування, виступав високий рівень невизначеності щодо подальшого економічного розвитку та обмежене коло надійних позичальників.

Загалом, серйозні проблеми в економіці України спричинила нестабільна ситуація в країні, в тому числі, внаслідок російської воєнної агресії. Держава значно втратила 3 економічного та інфраструктурного потенціалу. До суттєвого зниження платоспроможності суб'єктів господарювання та населення призвела девальвація гривні більше ніж втричі. В результаті наведених факторів, ускладнилося повернення валютних кредитів. Як наслідок, зросла проблемна заборгованість, що суттєво погіршило якість кредитних портфелів. НБУ здійснив «очищення» банківської системи. Такі дії НБУ спричинили наслідки як для банків, так i для економіки України. Ліквідація банківських установ призвела до великих фінансових втрат вкладників та кредиторів банків. Зазначимо, що темпи зростання ВВП за період 2016-2018 p.p. дещо активніші, ніж обсяги наданих кредитів. До настання системної банківської кризи спостерігався практично лінійний зв'язок між названими показниками. Після початку системної банківської кризи суттєвого збільшення розміру кредитів не спостерігається. Водночас, ВВП зростає досить швидкими темпами. Вважаємо, що головною причи- 
ною такого явища $€$ певна недовіра суспільства до банків.

На думку багатьох фахівців, економіка України втратила від 30 до 50 \% кредитної підтримки банківського сектору. Вважаємо, що частина банківських кредитних ресурсів обслуговує надлишкову ліквідність банків. Зокрема, ліквідність має високі показники та нерівномірно розподілена між банками. Тобто, значні обсяги мобілізованих банками коштів не спрямовуються на кредитування та стимулювання розвитку економіки.

Висновки. Підсумовуючи викладене, відзначимо, що взаємодія реального сектору економіки 3 банками не зводиться тільки до однобічного процесу задоволення кредитними установами фінансових потреб підприємств. Реальний сектор економіки, в свою чергу, задовольняє потреби банків у капіталізації, формуванні ресурсної бази, розміщенні вільних грошових коштів. Таким чином, банківський i реальний сектори не тільки взаємодіють, а й взаємозалежні.

Вважаємо, що питання фінансової та економічної безпеки банків доцільно розглядати враховуючи наступні виклики та загрози:

1) дестабілізація політичної ситуацї;

\section{Список використаної літератури}

1. Барановський О. І. Філософія безпеки: монографія: у 2 т. К.: УБС НБУ, 2014. Т. 2: Безпека фінансових інститутів. 715 с.

2. Варналій 3.С., Томашевський Т.Т. Місце фінансової безпеки в системі економічної безпеки України. International scientific journal «Internauka».Series: «Economic sciences». 2018. № 8 (16). 
3.

Гуцал, I. Мотиваційні фактори у забезпеченні ефективності кредитування. Банківська справа. 2002. №3. С. 38-45.

4. Дзюблюк О.В., Малахова О.Л. Банки і підприємства: кредитні аспекти взаємодії в умовах ринкової трансформації економіки: Монографія. Тернопіль: Вектор. 2008. 324 с.

5. З Звєряков M.І., Жердецька Л.В. Банківський та реальний сектори економіки України: оцінка взаємозв'язків і детермінант розвитку. Економіка України, 2017. № 10 (671). С. 31-48.

6. Звіт про фінансову стабільність. Київ: НБУ. Грудень 2019 р. URL: https://old.bank.gov.ua/doccatalog/document?id=96887766.

7. Показники банківської системи. Національний банк України. 2019. URL:https://bank.gov.ua/control/uk/publish/article?art_id=34661442\&cat_id=34798 593 (дата звернення: 30.12.2019).

8. Про затвердження Методичних рекомендацій щодо розрахунку рівня економічної безпеки України: Наказ Міністерства економічного розвитку і торгівлі України від 29.10.2013 p. № 1277. URL: http://zakon.rada.gov.ua/rada/show/v1277731-13 (дата звернення: 26.12.2019 p.).

9. Тимошенко Ю.В., Ломакович В.А. Новий економічний курс України: стратегія інноваційного розвитку / за наук. ред. д.е.н. Т.С Унковської. Київ. 2018. $401 \mathrm{c}$.

10. Черничко Т.В. Інституційні засади організації кредитних відносин в Україні. Економічний аналіз, 2013. Том 14. № 1. С. 361-368.

11. Юрків Н.Я, Гладких Д.М. Розвиток банківського кредитування господарюючих суб'єктів як умова забезпечення сталого економічного зростання в Україні: Аналітична доповідь. Київ: Національний інститут стратегічних досліджень, 2019. URL: https://niss.gov.ua/doslidzhennya/analitichnimateriali/ekonomika/rozvitok-bankivskogo-kredituvannya-gospodaryuyuchikh.

12. Barro R.J. Determinants of economic growth: a crosscountry empirical study. NBER working paper series. 1996. August. 118 p. URL: http://www.nber.org/papers/w5698.

13. Dewan E., Hussein S. Determinants of Economic Growth. Working Paper 01/04. Economics Department Reserve Bank of Fiji. 2001. May. 52 p. 